\title{
PARTITION RESOURCES SOIL AND LIGHT IN COMPETITION BETWEEN SOYBEAN (Glycine max) AND STAGES OF HORSEWEED (Conyza bonariensis)
}

\author{
Diecson Ruy Orsolin da Silva ${ }^{1}$, Dirceu Agostinetto ${ }^{2}$, Leandro Vargas ${ }^{3}$
}

\footnotetext{
${ }^{1}$ Universidade Federal de Santa Maria. E-mail: diecsonros@hotmail.com

${ }^{2}$ Universidade Federal de Pelotas. E-mail: agostinetto@ig.com.br

${ }^{3}$ Embrapa Trigo. E-mail: leandro.vargas@embrapa.br
}

\section{ABSTRACT}

The objective of this work was to evaluate the competition for soil and light resources among soybean and horseweed at different development stages. The study was conducted in pots in the greenhouse, in a completely randomized design. The treatments consisted in the combination of the two horseweed development stages: horseweed rosetta (6 leaves) and horseweed $15 \mathrm{~cm}$ tall (25 leaves) under conditions of competition with soybean by resources of soil, light, soil + light and control without competition. Morphological variables of horseweed and soybean were evaluated at 43 days after culture emergence. The competition conditions for soil + light resources with the horseweed do not affect the development of the soybean independent of the weed development stage. The effects of the competition of horseweed of $15 \mathrm{~cm}$ tall for soil and light resources are greater than horseweed in the rosette stage.

Keywords: Interference, competitiveness, root, weed, solar radiation

\section{PARTIÇÃO DOS RECURSOS DE SOLO E LUZ NA COMPETIÇÃO ENTRE SOJA (Glycine max) E ESTÁDIOS DA BUVA (Conyza bonariensis)}

\section{RESUMO}

O objetivo do trabalho foi avaliar a competição pelos recursos de solo e luz entre soja e buva de diferentes estádios de desenvolvimento. $\mathrm{O}$ estudo foi realizado em casa de vegetação em delineamento inteiramente casualizado. Os tratamentos consistiram da combinação de dois estágios de desenvolvimento da buva: buva roseta ( 6 folhas) e buva de $15 \mathrm{~cm}$ de altura ( 25 folhas) sob condições de competição com soja pelos recursos: solo, luz, solo + luz e sem competição. Variáveis morfológicas da buva e da soja foram avaliadas aos 43 dias após a emergência da cultura. As condições de competição pelos recursos do solo e luz com buva não afetaram o desenvolvimento da soja independente do estádio 


\section{PARTITION RESOURCES SOIL AND LIGHT IN COMPETITION BETWEEN SOYBEAN (Glycine max) AND \\ STAGES OF HORSEWEED (Conyza bonariensis)}

de desenvolvimento. Os efeitos da competição da buva de $15 \mathrm{~cm}$ de altura pelos recursos do solo e luz são maiores comparado com a buva roseta.

Palavras-chave: Interferência, competitividade, raízes, planta daninha, radiação solar

\section{INTRODUCTION}

Soybean crop has become Brazil's main export agricultural grain, and in the 2016/17 crop, more than 33.9 million ha were cultivated and a production exceeding 109 million tons (CONAB, 2018). In recent years, with the development of biotechnology focused on agriculture, the grain production has been growing, obtaining higher yields with less area used. Among the factors that contributed to this growth were the development of glyphosate-resistant crops, which allowed farmers to simplify weed control in soybeans, replacing the use of several herbicides with a single molecule (SHANER, 2000). However, the increased use of glyphosate for weed control in glyphosate-resistant soybeans led to the selection of resistant biotypes, such as horseweed (Conyza bonariensis) (VARGAS et al., 2007).

The horseweed has high competitiveness and dispersive potential, presenting an emergency flow throughout the year, which causes different stages of plants to occur during a cycle crop, which affects the ability of competition. As the horseweed establishment occurred before soybean planting, the weed presents a competitive advantage in relation to the crop, and the negative effects of its presence increase as its emergence is anticipated in relation to the crop. Studies with establishment of the weed before crop show that the delay in the emergence of soybean in relation to the weed increases the negative effects, which can be potentiate with the rise of the population (FLECK et al., 2004; SILVA et al., 2005; RIZZARDI et al., 2004).

The interferences relationships between crops and weeds depend on the conditions under which is occurring, as competition interactions depend on the weed species and population and environmental conditions. In general, crops are less efficient in competition due to the occurrence of weeds in greater number, in addition to the anticipated emergence, which confers a greater ability to extract resources from the environment (PROCÓPIO et al., 2005).

The competition for water, soil nutrients and light limits the growth of plants in the environment. To determine the effect of root and shoot competition independently, some methodologies have been used to allow separation of each factor. In controlled environment conditions, three methods are used: divided pots, in-line plants and target plants, and the choice of each method depends on its advantages and limitations (MCPHEE \& AARSSEN, 2001). 
The methods of divided pots and plants in lines are similar and allows the competition of plants between all the compartments (null competition, by soil resources or light and soil + light). Already, the target plant method consists of a target plant surrounded by neighboring weeds. This method has the advantage of light competition being more realistic than other methodologies; on the other hand, studies in additive series, is not possible to isolate the competition for aerial parts and roots.

It is hypothesized that larger horseweed plants cause greater damage to the development of soybean compared to smaller plants, and are less competitive than soybean by light or soil resources. The objective of this work was to evaluate the competition for soil and light resources among soybean and horseweed at different development stages.

\section{MATERIAL AND METHODS}

Experiments conducted during October 2011 and February 2012 in Passo Fundo, Rio Grande do Sul State, Brazil at Experimental Station of Embrapa Trigo. Two experiments were conducted in a greenhouse in a completely randomized design, with four replications. The tests were placed in $8.0 \mathrm{~L}$ plastic pots, and the soil in use was a clayey, typical Dystrophic Red Latosol with the following physicochemical properties (EMBRAPA, 1997): clay $=53 \%$; organic matter $=2.3 \mathrm{~g} \cdot \mathrm{dm}^{-3}$; water $\mathrm{pH}=$ 7.3; $\mathrm{P}=50 \mathrm{mg} \cdot \mathrm{dm}^{-3} ; \mathrm{K}=496 \mathrm{mg} \cdot \mathrm{dm}^{-3} ; \mathrm{Ca}=82.8 \mathrm{mmolc} \cdot \mathrm{dm}^{-3} ;$ and $\mathrm{Mg}=49.4 \mathrm{mmolc} \cdot \mathrm{dm}^{-3}$.

To determine the maximum number of soybean and horseweed plants that the pots support, a preliminary experiment (experiment $\mathrm{I}$ ) was conducted in additive series to determine the plant population from which the shoot dry matter (SDM) per unit area becomes independent of the population, according to the "law of constant final yield" (RADOSEVICH et al., 1997). The experimental design was completely randomized, on a $2 \times 5$ factorial, where the treatments consisted in the two plants: soybean and horseweed in monoculture, and with five populations: 2, 4, 8, 16, and 32 plants per pot (equivalent to 52, $105,210,420,841$ plants per square meter). Seeds of horseweed were germinated in plastic pots (500 $\mathrm{mL}$ ) and when with four leaves were finally transplanted in the experimental units, while the soybean seeds were sown directly in the experimental units. The horseweed and soybean was transplanted and sowing, respectively, in the same time. The SDM of plants were analyzed at 43 days after emergence (DAE), by weighing the dried material in an oven, with a temperature of $60^{\circ} \mathrm{C}$ for 72 hours. This preliminary experiment resulted in a SDM production constant with a population of soybean and horseweed of the 210 and 420 plants $\mathrm{m}^{-2}$, respectively. Thus, the number of plants used for the subsequent 
experiment was four and eight plants for soybean and horseweed, respectively, for each half of the pot (Figure 1).

The experiment II was developed in the 2 x 4 factorial scheme, where the treatments consisted in the combination of the two development stages of horseweed under four competitions with soybean. The development stages of horseweed were: stage rosette (6 leaves) and horseweed with $15 \mathrm{~cm}$ of height (25 leaves). The competition conditions between soybean and horseweed were: no competition (Null); Competition for soil and light resources (Soil + Light); Competition for soil resources (Soil); and competition for light (Light) (Figure 1). The horseweed plants were collected in the field and transplanted to the experimental units and the soybean cultivar used was BRS Estância RR (maturation group 6.1 and determinate growth habit).

The plant row method was used, with the use of lateral divisions, allowing the isolation of the plants according to each studied treatment. In order to separate the competition conditions, polyethylene partitions were used both in the soil and light competition conditions, the shoot partition were used coated with an aluminum film to reflect the solar radiation and to maintain the light intensity inside the experimental unit (Figure 1).

$\mathbf{A}$

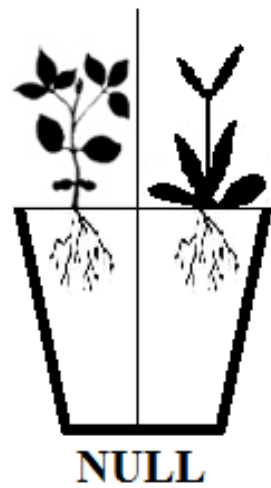

B

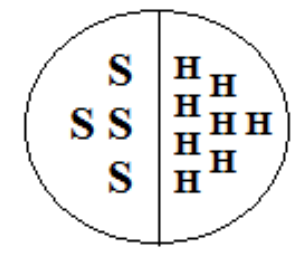

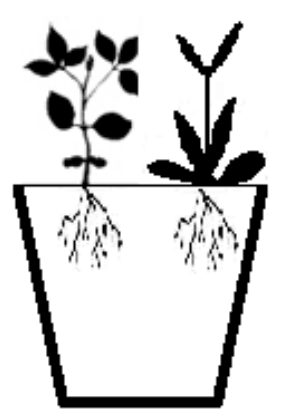
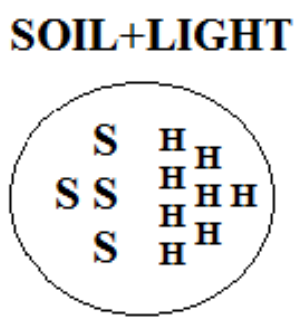

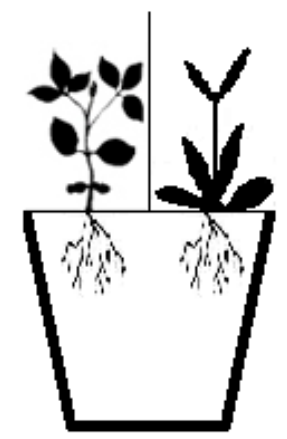

SOIL

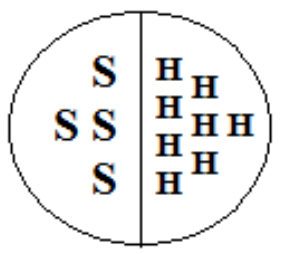

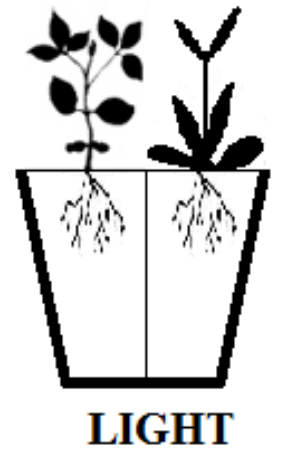

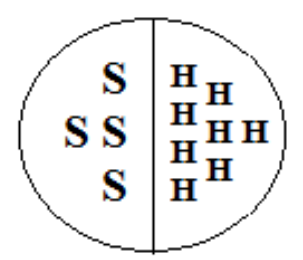

Figure 1. Conditions of competition scheme (A - side view) and distribution of plants in pots (B - top view). "S" and "H" represent soybean and horseweed, respectively.

At 43 DAE, the plant height (PH), leaf area (LA), leaf dry matter (LDM), stem dry matter (StDM) and SDM of the soybean plants were determined, and PH and SDM in the horseweed plants. Plant height 
was obtained by measuring the distance from the base of the plant to the end of the last fully developed leaf. LA was obtained with the aid of a leaf area meter, model LICOR 3100. LDM and StDM were obtained by weighing the parts after drying in an oven with air circulation at $60{ }^{\circ} \mathrm{C}$ for 72 hours, and SDM was obtained by summing the LDM and StDM. For soybean plants were calculated: leaf area index = leaf area / pot surface area; leaf area ratio = leaf area / g plant; specific leaf area = leaf area / leaf dry matter, and leaf mass ratio = leaf dry matter / shoot dry matter. The use of these equations was to indicate the allocation of photoassimilates through by the leaf mass ratio and leaf area ratio and leaf expansion by specific leaf area and leaf area index.

The data obtained were verified for homogeneity and submitted to ANOVA by the F test (p> 0.05 ), in case of significance, the development stage of horseweed were compared by the " $t$ " test ( $p>$ $0.05)$, and the competition conditions were compared by Duncan test ( $p>0.05$ ).

\section{RESULTS AND DISCUSSION}

There was no interaction between the competition conditions and development stage of horseweed for the growth variables of soybean. The competition conditions did not affect the soybean height when in competition with horseweed rosette or horseweed of $15 \mathrm{~cm}$ tall (Table 1). However, soybean height was superior when in competition with horseweed rosette by separate soil and light resources than horseweed of $15 \mathrm{~cm}$ tall, producing approximately $17 \%$ more. The competition conditions had an effect only on horseweed of $15 \mathrm{~cm}$, where horseweed height was reduced in the competition with soybean by the light resource. The rapid growth in height is a desirable characteristic to suppress competition between crop and weed, giving competitive advantages in competition for light, allowing the culture to shade the species competitors (OGG Jr \& SEEFELDT, 1999).

The height response may vary depending on the type of resource that may be required. Under limiting water and soil nutrient conditions, weed competition can reduce soybean height, however, when soil resources are not limiting, soybean height may be higher in the competition condition, thus light has greater influence in the interactions of competition (VOLLMANNA et al., 2010). In an experiment conducted by Trezzi et al. (2013) regarding the competitive ability of soybean cultivars in competition with horseweed, the authors have verified that soybean height may be higher in the presence of the weed. 
Table 1. Effect of development stage of horseweed and competition conditions on the soybean and horseweed plant height $(\mathrm{cm})$

\begin{tabular}{lcccc}
\hline Competition & \multicolumn{2}{c}{ Soybean height } & \multicolumn{2}{c}{ Horseweed height } \\
\cline { 2 - 5 } conditions & Rosette & $15 \mathrm{~cm}$ tall & $* 19.37 \mathrm{a}$ & $62.25 \mathrm{ab}$ \\
\hline Soil & $* 101.75 \mathrm{a}$ & $87.63 \mathrm{a}$ & $* 18.33 \mathrm{a}$ & $58.75 \mathrm{~b}$ \\
Light & $* 108.33 \mathrm{a}$ & $92.25 \mathrm{a}$ & $* 16.63 \mathrm{a}$ & $60.25 \mathrm{ab}$ \\
Soil + Light & ${ }^{\mathrm{ns}} 95.75 \mathrm{a}$ & $88.87 \mathrm{a}$ & $* 19.87 \mathrm{a}$ & $72.50 \mathrm{a}$ \\
Null & $\mathrm{ns} 96.00 \mathrm{a}$ & $93.75 \mathrm{a}$ & & 21.9 \\
\hline $\mathrm{CV}(\%)$ & \multicolumn{3}{c}{9.2} & \\
\hline
\end{tabular}

Means followed by same letter in column do not differ significantly by Duncan test $(\mathrm{p}<0.05) .{ }^{*}$ and ${ }^{\text {ns }}$ indicated significant and not significant, respectively, in the comparison between the stages of horseweed by the " $\mathrm{t}$ " test $(\mathrm{p} \leq 0,05)$.

The results observed for light and soil competition of soybean between two stages of horseweed, indicated the manifesting effects of the so-called shade avoidance, which impacts on the increment of the height of the plant established later (GREEN-TRACEWICZ et al., 2012; AFIFI \& SWANTON, 2012, LAMEGO et al., 2015). The changes in the quality and intensity of light, especially in the red and red extreme light $(\mathrm{V} / \mathrm{Ve})$ incident on plants, may affect the development of soybean plants (BALLARÉ et al., 1990). On the other hand, the horseweed of $15 \mathrm{~cm}$ tall had a reduced height in competition for light.

The competition conditions did not affect the shoot dry matter of soybean in competition with one or the other stage development of horseweed (Table 2). Only an effect was verified between the stages development of horseweed, being that the horseweed of $15 \mathrm{~cm}$ tall caused significant damages on the soybean for soil and light competition, compared of horseweed rosette (Table 2). In the soil competition resources, the horseweed of $15 \mathrm{~cm}$ tall caused a reduction of $30 \%$ in shoot dry mass, while in light competition the reduction was 36\%. Bianchi et al. (2006) found that the competition condition for soil resources was more important for soybean competition with competitor plants. The increase in soybean biomass is related to the increase in soybean yield; however, when in the competition with weed, the response of the plant is very variable as the biomass increase, which reflects in variability in yield (GREEN-TRACEWICZ et al., 2011).

The horseweed rosette stage had lowed shoot dry matter under competition for light and soil + light with soybean when compared to competition by the soil resource (Table 2). Despite this, the horseweed of $15 \mathrm{~cm}$ tall did not have its shoot dry matter altered as a function of the competition 
conditions. In general, plants that present greater growth and development of root mass are more competitive, mainly due to the greater ability to extract water and nutrients (GRIEU et al., 2001).

Table 2. Effect of development stage of horseweed (rosette and $15 \mathrm{~cm}$ tall) and competition conditions on soybean and horseweed shoot dry matter $(\mathrm{g})$

\begin{tabular}{lcccc}
\hline Competition & \multicolumn{2}{c}{ Shoot dry matter - Soybean } & \multicolumn{2}{c}{ Shoot dry matter - Horseweed } \\
\cline { 2 - 5 } conditions & Rosette & $15 \mathrm{~cm}$ tall & Rosette & $15 \mathrm{~cm}$ tall \\
\hline Soil & $* 21.40 \mathrm{a}$ & $14.89 \mathrm{a}$ & $* 1.92 \mathrm{a}$ & $5.76 \mathrm{a}$ \\
Light & $* 23.78 \mathrm{a}$ & $15.15 \mathrm{a}$ & $* 0.83 \mathrm{~b}$ & $4.93 \mathrm{a}$ \\
Soil + Light & ${ }^{n s} 22.95 \mathrm{a}$ & $16.50 \mathrm{a}$ & $* 1.14 \mathrm{~b}$ & $4.86 \mathrm{a}$ \\
Null & ${ }^{n s} 19.19 \mathrm{a}$ & $16.58 \mathrm{a}$ & $* 1.44 \mathrm{ab}$ & $8.42 \mathrm{a}$ \\
\hline $\mathrm{CV}(\%)$ & \multicolumn{3}{c}{47.9} \\
\hline
\end{tabular}

Means followed by same letter in column do not differ significantly by Duncan test $(\mathrm{p}<0.05) .{ }^{*}$ and ${ }^{\mathrm{ns}}$ indicated significant and not significant, respectively, in the comparison between the stages of horseweed by the " $\mathrm{t}$ " test $(\mathrm{p} \leq 0,05)$.

The competition for soil resources, mainly water and soil nutrients, may not have had significant effects due to the fact that these factors are not limiting due to soil characteristics (soil fertility and water retention capacity) and periodic irrigations on this experiments. Thus, changes in soil competition conditions may be due to other associations between the roots as allelopathic effects (HU \& ZHANG, 2013). However, the spatial occupation ability of the roots is of primary importance in the competition for soil resources, and the relative growth rate, biomass, root hair density, and surface area are the characteristics necessary for a plant to have a good competitive ability (CASPER \& JACKSON, 1997).

No significance differences were observed in relation of the competition conditions for soybean leaf area, leaf dry matter and stem dry matter (Table 3). However, in light competition, the horseweed $15 \mathrm{~cm}$ tall caused more injury on soybean leaf area, compared to horseweed rosette in the soil and soil + light competition. In all the competition conditions (soil, light and soil + light), the horseweed $15 \mathrm{~cm}$ tall caused significant losses in the soybean leaf dry matter and stem dry matter. The shading is a characteristic related to the leaf area of the plants, and determines the degree of importance in the competition for solar light (MORALES-PAYAN et al., 2003). Thus, weed with superior plant height are capable of causing major injuries in the crops.

Before interfering relations occur, plants detect early responses from the environment, especially the light that is reflected from other plants and alter their metabolism to prevent shading of other plants, 
and the soybean crop has the capacity to occupy spaces with increased branching, and this plasticity gives it a competitive advantage (BALLARÉ et al., 1990; GREEN-TRACEWICZ et al., 2011). Although there may be no differences in soybean biomass in the initial competition with horseweed, the yield soybean is negatively affected by the presence of the competitor (TREZZI et al., 2013; SILVA et al., 2014).

Table 3. Effect of development stage of horseweed (rosette and $15 \mathrm{~cm}$ tall) and competition conditions on soybean leaf area $\left(\mathrm{cm}^{2}\right)$, leaf dry matter $(\mathrm{g})$ and stem dry matter $(\mathrm{g})$

\begin{tabular}{lcccccc}
\hline \multirow{2}{*}{$\begin{array}{l}\text { Competition } \\
\text { conditions }\end{array}$} & \multicolumn{2}{c}{ Leaf area } & \multicolumn{2}{c}{ Leaf dry matter } & \multicolumn{2}{c}{ Stem dry matter } \\
\cline { 2 - 6 } & Rosette & $15 \mathrm{~cm}$ tall & Rosette & $15 \mathrm{~cm}$ tall & Rosette & $15 \mathrm{~cm}$ tall \\
\hline Soil & ${ }^{\mathrm{ns}} 2994 \mathrm{a}$ & $2443 \mathrm{a}$ & $* 10.32 \mathrm{a}$ & $7,04 \mathrm{a}$ & $* 11.09 \mathrm{a}$ & $7.86 \mathrm{a}$ \\
Light & $* 3642 \mathrm{a}$ & $2456 \mathrm{a}$ & $* 11.84 \mathrm{a}$ & $7,00 \mathrm{a}$ & $* 11.94 \mathrm{a}$ & $8.16 \mathrm{a}$ \\
Soil + Light & ${ }^{\mathrm{ns}} 3301 \mathrm{a}$ & $2647 \mathrm{a}$ & $* 11.63 \mathrm{a}$ & $7,54 \mathrm{a}$ & $* 11.32 \mathrm{a}$ & $8.97 \mathrm{a}$ \\
Null & $* 3048 \mathrm{a}$ & $2507 \mathrm{a}$ & $* 9.52 \mathrm{a}$ & $7,54 \mathrm{a}$ & ${ }^{n} 9.68 \mathrm{a}$ & $9.05 \mathrm{a}$ \\
\hline $\mathrm{CV}(\%)$ & \multicolumn{3}{c}{15.1} & \multicolumn{3}{c}{14.2} \\
\hline
\end{tabular}

Means followed by same letter in column do not differ significantly by Duncan test $(\mathrm{p}<0.05) .{ }^{*}$ and ${ }^{\mathrm{ns}}$ indicated significant and not significant, respectively, in the comparison between the stages of horseweed by the " $\mathrm{t}$ " test $(\mathrm{p} \leq 0,05)$.

The development of weeds has a direct relationship with the negative effects on crop competition, where it can be verified that plants emerged before soybean cause a delay in crop development (SILVA et al., 2005). The early emergence of hair beggarticks and arrowleaf sida in relation to soybean causes a decrease in morphological characteristics and crop yield (FLECK et al., 2004).

The foliar expansion indicators (leaf area index and specific leaf area) showed that competition for light was more important and the leaf area index was reduced 33\% and the specific leaf area increase $14 \%$ when competing with horseweed $15 \mathrm{~cm}$ tall (Table 4). The lower specific leaf area in the competition indicates that photoassimilates of the leaves were more used for leaf expansion, that is, it directs the plants produce a larger leaf area per leaf mass (BIANCHI et al.,2006). Thus, in competition for light with horseweed of $15 \mathrm{~cm}$ tall, the soybean produced thinner and larger leaves compared with horseweed rosette. Variations in the morphological response of soybeans were also observed by Green-Tracewicz et al., (2011): according to the authors, the soybean plasticity allows the plant adapt to the different environment conditions and thus the soybean could express a increase of leaf area, however with a great variability between plants. 
Table 4. Effect of development stage of horseweed (rosette and $15 \mathrm{~cm}$ tall) and competition conditions on soybean leaf area index $\left(\mathrm{cm}^{2}\right.$ leaf $/ \mathrm{cm}^{2}$ soil $)$, specific leaf area $\left(\mathrm{cm}^{2}\right.$ leaf $/ \mathrm{g}$ leaf $)$, leaf area ratio $\left(\mathrm{cm}^{2} / \mathrm{g}\right.$ plant) and leaf matter ratio (g leaf / g plant).

\begin{tabular}{|c|c|c|c|c|c|c|c|c|}
\hline \multirow{2}{*}{$\begin{array}{l}\text { Competition } \\
\text { conditions }\end{array}$} & \multicolumn{2}{|c|}{ Leaf area index } & \multicolumn{2}{|c|}{ Specific leaf area } & \multicolumn{2}{|c|}{ Leaf area ratio } & \multicolumn{2}{|c|}{ Leaf mass ratio } \\
\hline & Rosette & $15 \mathrm{~cm}$ tall & Rosette & $15 \mathrm{~cm}$ tall & Rosette & $15 \mathrm{~cm}$ tall & Rosette & $15 \mathrm{~cm}$ tall \\
\hline Soil & ${ }^{\mathrm{n} s} 14.4 \mathrm{a}$ & $11.8 \mathrm{a}$ & ns290a & $344 a$ & ${ }^{\mathrm{ns}} 139 \mathrm{~b}$ & $162.9 \mathrm{a}$ & ${ }^{\mathrm{ns}} 0.482 \mathrm{a}$ & $0.474 \mathrm{a}$ \\
\hline Light & $* 17.5 \mathrm{a}$ & $11.8 \mathrm{a}$ & *307a & $351 \mathrm{a}$ & ${ }^{\mathrm{ns}} 153 \mathrm{ab}$ & $162.2 \mathrm{a}$ & ${ }^{*} 0.499 \mathrm{a}$ & $0.462 \mathrm{a}$ \\
\hline Soil + Light & ${ }^{\mathrm{ns}} 15.9 \mathrm{a}$ & $12.7 \mathrm{a}$ & ${ }^{n s} 286 a$ & $349 a$ & ${ }^{\mathrm{ns}} 144 \mathrm{ab}$ & $159.2 \mathrm{a}$ & ${ }^{*} 0.506 \mathrm{a}$ & $0.457 \mathrm{a}$ \\
\hline Null & ${ }^{\mathrm{ns}} 14.7 \mathrm{a}$ & $12.1 \mathrm{a}$ & ${ }^{\mathrm{n}} 322 \mathrm{a}$ & $333 a$ & ${ }^{\mathrm{ns}} 160 \mathrm{a}$ & $151.6 a$ & ${ }^{*} 0.496 \mathrm{a}$ & $0.455 a$ \\
\hline $\mathrm{CV}(\%)$ & & 15.0 & & 11.6 & & 9.2 & & 4.9 \\
\hline
\end{tabular}

Means followed by same letter in column do not differ significantly by Duncan test $(\mathrm{p}<0.05) .{ }^{*}$ and ${ }^{\text {ns }}$ indicated significant and not significant, respectively, in the comparison between the stages of horseweed by the " $\mathrm{t}$ " test $(\mathrm{p} \leq 0,05)$.

The soybean leaf area ratio indicated differences only in the competition conditions for horseweed rosette, and showed that the competition for the soil resources reduces the soybean's ability to intercept light energy, in relation to null competition, indicating reduced partition of photoassimilates to the leaves (lower leaf area ratio) (Table 4). The leaf area ratio is an important morphophysiological indicator, as it relates to the area of interception of light energy and $\mathrm{CO}_{2}$ and the accumulation of total dry mass, which is the result of $\mathrm{CO}_{2}$ fixation by plants. When competition for light resources does not occur, the plant tends to direct the allocation of photoassimilates to other non-leaves, like roots and stem. Thus, the result of the lower leaf area ratio in the competition condition by soil resources may be an indication of the orientation of photoassimilates.

The competition with horseweed of $15 \mathrm{~cm}$ tall reduced the leaf mass ratio of the soybean in the competition for light, soil + light and null, in relation to competition with horseweed rosette (Table 4). Thus, the soybean plants directed the allocation of assimilated to the leaves instead of stem, branches and petioles in the competition with horseweed rosette. The greater distribution of assimilated for leaf formation increases the ability of plants to shade competing plants and represents a fundamental requirement for competitive success (BALBINOT Jr. et al., 2003).

Competition losses may be related to the quantity and quality of light that reaches the canopy of plants. It has been reported that, under noncompetitive conditions, changes in the light quality reflected by weeds causes changes in competition interactions with crops (LIU et al., 2009). The increase in plant height, length of nodes, the increase of the shoot/roots ratio are morphological alterations that indicate 
competition for light, or the modification of the relation of light quality that reaches the plants (GREEN-

TRACEWICZ et al., 2011).

\section{CONCLUSIONS}

The conditions of competition for soil + light resources with horseweed do not affect the soybean growth, independent of the stage development of horseweed. The effects of the competition of horseweed of $15 \mathrm{~cm}$ tall for soil and light resources are greater than horseweed in the rosette stage.

\section{REFERENCES}

AFIFI, M.; SWANTON, C. 2012. Early physiological mechanisms of weed competition. Weed Science, Lawrence, v. 60, n. 4, p. 542-551.

BALBINOT Jr., A.A.; FLECK, N.G.; BARBOSA NETO, J.F.; RIZZARDI, M.A. 2003. Características de plantas de arroz e a habilidade competitiva com plantas daninhas. Planta Daninha, Viçosa, v. 21, n. 2, p. 165-174.

BALLARÉ, C.L.; SCOPEL, A.L.; SÁNCHEZ, R.A. 1990. Far-red radiation reflected from adjacent leaves: an early signal of competition in plant canopies. Science, Washington, v. 247, n. 19, p. 329332.

BIANCHI, M.A.; FLECK, N.G.; DILLENBURG, L.R. 2006. Partição da competição por recursos do solo e radiação solar entre cultivares de soja e genótipos concorrentes. Planta Daninha, Viçosa, v.21, n.4, p.629-639.

CASPER, B.B.; JACKSON, B.R. 1997. Plant competition underground. Annual reviews Ecology Systemic, Palo Alto, v. 28, n. 1, p. 545-570.

CONAB. Companhia Nacional de Abastecimento. Acompanhamento da safra brasileira de grãos: Safra 2017/2018, quarto levantamento. Janeiro/2018. Available in: <http://www.conab.gov.br/OlalaCMS/uploads/arquivos/18_01_11_14_17_49_graos_4o_levantamen to.pdf $>$. Acessed in 31 jan. 2018.

EMPRESA BRASILEIRA DE PESQUISA AGROPECUÁRIA - EMBRAPA. 1997. Centro Nacional de Pesquisa de Solos. Manual de métodos de análise de solo. 2.ed. Rio de Janeiro. 212 p.

FLECK, N.G.; RIZZARDI, M.A.; AGOSTINETTO, D.; BALBINOT Jr. A.A. 2004. Interferência de picão-preto e guanxuma com a soja: efeitos da densidade de plantas e épocas relativa de emergência. Ciência Rural, Santa Maria, v. 34, n. 1, p. 41-48.

GREEN-TRACEWICZ, E.; PAGE, E.R.; SWANTON, C.J. 2011. Shade avoidance in soybean reduces branching and increases plant-to-plant variability in biomass and yield per plant. Weed Science, Lawrence, v. 59, n. 1, p. 43-49.

GREEN-TRACEWICZ, E.; PAGE, E.R.; SWANTON, C.J. 2012. Light quality and the critical period for weed control in soybean. Weed Science, Lawrence, v. 60, n. 1, p. 86-91,

GRIEU, P.; LUCERO, D.W.; ARDIANI, R.; EHLERINGER, J.R. 2001. The mean depth of soil water uptake by two temperate grassland species over time subjected to mild soil water deficit and competitive association. Plant and Soil, Crawley, v. 230, n. 2, p. 197-209.

HU, G.; ZHANG, Z.H. 2013. Aqueous tissue extracts of Conyza canadensis inhibit the germination and shoot growth of three native herbs with no autotoxic effects. Planta Daninha, Viçosa, v. 31, n. 4, p. 805-811. 
LAMEGO, F.P.; REINEHR, M.; CUTTI, L.; AGUIAR, A.C.M.; RIGON, C.A.G.; PAGLIARINI, I.B. 2015. Alterações morfológicas de plântulas de trigo, azevém e nabo quando em competição nos estádios iniciais de crescimento. Planta Daninha, Viçosa, v. 33, n. 1, p. 13-22.

LIU, J.G.; MAHONEY, K.J.; SIKKEMA, P.P.; SWANTON, C.J. 2009. The importance of light quality in crop-weed competition. Weed Research, Chichester, v. 49, n. 2, p. 217-224.

McPHEE, C. S.; AARSSEN, L. W. 2001. The separation of above and below-ground competition in plants. A review and critique of methodology. Plant Ecology, Dordrecht, v. 152, n. 2, p.119-136.

MORALES-PAYAN, J. P.; STALL, W.M.; SHILLING, D.G.; CHARUDATTAN, R.; DUSKY, J.A.; BEWICK, T.A. 2003. Above- and below-ground interference of purple and yellow nutsedge (Cyperus spp.) with tomato. Weed Science, Lawrence, v. 51, n. 2, p.181-185.

OGG Jr.A.G.; SEEFELDT, S.S. 1999. Characterizing trais that enhance the competitiveness of winter wheat (Triticum aestivum) against jointed goatgrass (Aegilops cylindrica). Weed Science, Lawrence, v. 47, n. 1, p.74-80.

PROCÓPIO, S.O.; SANTOS, J.B.; PIRES, F.R.; SILVA, A.A.; MENDONÇA, E.S. 2005. Absorção e utilização do fósforo pelas culturas da soja e do feijão e por plantas daninhas. Revista Brasileira de Ciência do Solo, Viçosa, v. 29, n. 6, p. 911-921.

RADOSEVICH, S. R.; HOLT, J.; GUERSA, C. 1997. Weed ecology: implications for management. 2.ed. New York: Willey. 589 p.

RIZZARDI, M.A.; ROMAN, E.S.; BOROWSKI, D.Z.; MARCON, R. 2004. Interferência de populações de Euphorbia heterophylla e Ipomoea ramosissima isoladas ou em misturas sobre a cultura de soja. Planta Daninha, Viçosa, v. 22, n. 1, p. 29-34.

SHANER, D. 2000. Impact of glyphosate-tolerant crops on the use of others herbicides and on resistance management. Pesticide Science, Malden, v. 56, n. 4, p. 320-326.

SILVA, A.C.; FERREIRA, L.R.; SILVA, A.A.; FREITAS, R.S.; MAURO, A. 2005. Épocas de emergência de Brachiaria brizantha no desenvolvimento da cultura da soja. Ciência Rural, Santa Maria, v. 35, n. 4, p. 769-775.

SILVA, D.R.O.; VARGAS, L.; AGOSTINETTO, D.; MARIANI, F. 2014. Glyphosate-resistant hairy fleabane competition in $\mathrm{RR}^{\circledR}$ soybean. Bragantia, Campinas, v. 73, n. 4, p. 451-457.

TREZZI, M.M.; BALBINOT JR., A.A.; BENIN, G.; DEBASTIANI, F.; PATEL, F.; MIOTTO JR., E. 2013. Competitive ability of soybean cultivars with horseweed (Conyza bonariensis). Planta Daninha, Viçosa, v. 31, n. 3, p. 543-550.

VARGAS, L.; BIANCHI, M.A.; RIZZARDI, M.A.; AGOSTINETTO, D.; DAL MAGRO, T. 2007. Horseweed (Conyza bonariensis) resistente ao glyphosate na região sul do Brasil. Planta Daninha, Viçosa, v. 25, n. 3, p. 573-578.

VOLLMANNA, J.; WAGENTHERSTL, H.; HARTL, W. 2010. The effects of simulated weed pressure on early maturity soybeans. European Journal of Agronomy, Taastrup, v. 32, n. 4, p. 243-248. 